\title{
Disinfection Kinetics and Contribution of Reactive Oxygen Species When Eliminating Bacteria with $\mathrm{TiO}_{2}$ Induced Photocatalysis
}

\author{
Yanling Cai*, Maria Strømme, Ken Welch* \\ Division for Nanotechnology and Functional Materials, Department of Engineering Sciences, The Ångström \\ Laboratory, Uppsala University, Uppsala, Sweden \\ Email: ${ }^{*}$ yanling.cai@angstrom.uu.se, ${ }^{*}$ ken.welch@angstrom.uu.se
}

Received 12 June 2014; revised 11 July 2014; accepted 24 July 2014

Copyright $@ 2014$ by authors and Scientific Research Publishing Inc.

This work is licensed under the Creative Commons Attribution International License (CC BY). http://creativecommons.org/licenses/by/4.0/

(c) (i) Open Access

\section{Abstract}

Titania $\left(\mathrm{TiO}_{2}\right)$ induced photocatalysis has been widely investigated and applied as a disinfection strategy in many industrial and clinical applications. Reactive oxygen species (ROS), including hydroxyl radicals $(\bullet \mathrm{OH})$, superoxide radicals $\left(\mathrm{O}_{2}^{--}\right)$and hydrogen peroxide $\left(\mathrm{H}_{2} \mathrm{O}_{2}\right)$, generated in the photocatalytic reaction process are considered to be the active components prompting the bactericidal effect. In the present work, the kinetics of photocatalytic inactivation of Staphylococcus epidermidis and specific contributions of $\bullet \mathrm{OH}, \mathrm{O}_{2}^{--}$and $\mathrm{H}_{2} \mathrm{O}_{2}$ to the bactericidal process were studied using two disinfection settings sutilizing photocatalytic resin- $\mathrm{TiO}_{2}$ nanocomposite surfaces and suspended $\mathrm{TiO}_{2}$ nanoparticles, respectively. In antibacterial tests against $S$. epidermidis with a layer of bacterial suspension on the resin- $\mathrm{TiO}_{2}$ surfaces, $\mathrm{H}_{2} \mathrm{O}_{2}$ was found to be the most efficient ROS component contributing to the antibacterial effect. Disinfection kinetics showed a two-step behavior with an initial region having a lower disinfection rate followed by a higher rate region after 10 min of UV irradiation. By contrast, in antibacterial tests with suspended bacteria and photocatalytic $\mathrm{TiO}_{2}$ nanoparticles, $\bullet \mathrm{OH}$ and $\mathrm{H}_{2} \mathrm{O}_{2}$ showed equal significance in the bacterial inactivation having a typical Chick-Watson disinfection kinetics behavior with a steady disinfection rate. The results contribute to the understanding of the bactericidal mechanism and kinetics of photocatalytic disinfection that are essential for designing specific antibacterial applications of photocatalytic materials.

\section{Keywords}

Photocatalytic Disinfection, $\mathrm{TiO}_{2}$, Reactive Oxygen Species (ROS), Disinfection Kinetics

\footnotetext{
${ }^{*}$ Corresponding authors.
}

How to cite this paper: Cai, Y.L., Strømme, M. and Welch, K. (2014) Disinfection Kinetics and Contribution of Reactive Oxygen Species When Eliminating Bacteria with $\mathrm{TiO}_{2}$ Induced Photocatalysis. Journal of Biomaterials and Nanobiotechnology, $\mathbf{5}$, 200-209. http://dx.doi.org/10.4236/jbnb.2014.53024 


\section{Introduction}

Since Matsunaga et al. demonstrated the biocidal effect of $\mathrm{TiO}_{2}$ under metal halide lamp irradiation in 1985 [1], there has been an increasing interest in the application of the photocatalytic reaction of $\mathrm{TiO}_{2}$ as an alternative disinfection strategy to traditional chemical methods (e.g. alcohols, aldehydes, iodine, phenols and chlorine) or antibiotics [2] [3]. The photocatalytic reaction has been shown to be capable of killing a wide range of organisms, including Gram-negative and Gram-positive bacteria, fungi, algae, protozoa, viruses and bacteriophages [4] [5]. The mechanism of $\mathrm{TiO}_{2}$ induced photocatalysis involves the excitation of electrons from the valence band of this semiconductor to the conductive band through the absorption of light with sufficient energy (wavelength about $385 \mathrm{~nm}$ or less, depending on the size of the band gap). This results in the formation of electron-hole pairs with strong reducing and oxidizing potentials:

$$
\mathrm{TiO}_{2}+h v \rightarrow \mathrm{e}_{\mathrm{CB}}^{-}+\mathrm{h}^{+}{ }_{\mathrm{VB}}
$$

Primary oxidants, hydroxyl radicals $(\bullet \mathrm{OH})$, are generated on the hydrated metal oxide when $\mathrm{H}_{2} \mathrm{O}$ or $\mathrm{OH}^{-}$ reacts with the positive holes (Equations (2) and (3)). $\mathrm{Ti}^{\mathrm{IV}}$ sites in the titania crystals can trap the conduction band electrons and be reduced to $\mathrm{Ti}^{\mathrm{III}}$ sites, which can in turn react with the $\mathrm{O}_{2}$ adsorbed at $\mathrm{Ti}^{\mathrm{III}}$ sites and generate superoxide radicals $\left(\mathrm{O}_{2}^{--}\right)$(Equations (4) and (5)).

$$
\begin{gathered}
\mathrm{H}_{2} \mathrm{O}+\mathrm{h}^{+}{ }_{\mathrm{VB}} \rightarrow \cdot \mathrm{OH}+\mathrm{H}^{+} \\
\mathrm{OH}^{-}+\mathrm{h}^{+}{ }_{\mathrm{VB}} \rightarrow \cdot \mathrm{OH} \\
\mathrm{Ti}^{\mathrm{IV}}+\mathrm{e}^{-}{ }_{\mathrm{CB}} \rightarrow \mathrm{Ti}^{\mathrm{III}} \\
\mathrm{Ti}^{\mathrm{III}}+\mathrm{O}_{2} \rightarrow \mathrm{Ti}^{\mathrm{IV}}+\mathrm{O}_{2}^{--}
\end{gathered}
$$

Further reactions can also lead to the generation of hydrogen peroxide $\left(\mathrm{H}_{2} \mathrm{O}_{2}\right)$ (Equations (6) and (7)):

$$
\begin{gathered}
2 \mathrm{O}_{2}^{--}+2 \mathrm{H}^{+} \rightarrow \mathrm{H}_{2} \mathrm{O}_{2}+\mathrm{O}_{2} \\
2 \cdot \mathrm{OH} \rightarrow \mathrm{H}_{2} \mathrm{O}_{2}
\end{gathered}
$$

Hydroxyl radicals $(\cdot \mathrm{OH})$, superoxide radicals $\left(\mathrm{O}_{2}^{--}\right)$and hydrogen peroxide $\left(\mathrm{H}_{2} \mathrm{O}_{2}\right)$ are considered key reactive oxygen species (ROS) generated in the photocatalytic reaction [6]-[8]. In order to investigate the production, lifetime and diffusion coefficients of these ROS, methods incorporating detection probes specific to each species (see Table 1) have been established [9] [10]. The use of scavengers for $\bullet \mathrm{OH}, \mathrm{O}_{2}^{--}$and $\mathrm{H}_{2} \mathrm{O}_{2}$ (see Table 1) has also proved to be a reliable way of studying the involvement of ROS in the photocatalytic reaction [7] [8].

Understanding the bactericidal mechanism and kinetics of photocatalytic disinfectionis is essential for designing specific antibacterial applications of photocatalytic materials [6]. Consequently, extensive research on the mechanism of photocatalytic killing of bacteria has been conducted [1] [6] [14] [15]. Many possible extracellular [14] (e.g. peptidoglycan, polysaccharides and phospholipid) and intracellular (e.g. enzymes, coenzymes [1] and nucleic acid [15]) target sites for the ROS attack have been considered in studies of photocatalytic inactivation of bacteria. To date, the most convincing research suggests that the critical targets of ROS attack are polyunsaturated fatty acids and that the resulting lipid peroxidation is the key factor in the bactericidal effect [16] [17]. However, photocatalytic inactivation of bacteria is a complex process that involves reactions between the bacteria components and multiple types of ROS (e.g. $\bullet \mathrm{OH}, \mathrm{O}_{2}^{--}$and $\mathrm{H}_{2} \mathrm{O}_{2}$ ). Compared to the amount of research on the targeted bacterial components, the importance of each type of ROS in the bactericidal process has not re-

Table 1. Reactive oxygen species (ROS) generated in $\mathrm{TiO}_{2}$ induced photocatalysis and the corresponding scavengers and detection probes.

\begin{tabular}{ccc}
\hline ROS & Scavengers & Detection probes \\
\hline Hydroxyl radicals $(\cdot \mathrm{OH})$ & Mannitol, Glutathione & DMSO [11] \\
Hydrogen peroxide $\left(\mathrm{H}_{2} \mathrm{O}_{2}\right)$ & Catalase & Luminol [9] \\
Superoxide radicals $\left(\mathrm{O}_{2}^{--}\right)$ & Superoxide Dismutase (SOD) & Luminol, Lucigenin [12], NBT [12]*, MCLA [13] \\
\hline${ }^{*}$ MCLA: methoxy Cypridina luciferin analogue; NBT: nitrobluetetrazolium; DMSO: dimethyl sulfoxide.
\end{tabular}


ceived as much attention. In several studies [18]-[20], $\bullet \mathrm{OH}$ radicals are believed to be the main factor in bacterial inactivation while $\mathrm{H}_{2} \mathrm{O}_{2}$ has been shown to be the ROS responsible for long-range bactericidal effects [21]. Additionally, kinetics of the bactericidal process are important to understand for controlling parameters in disinfection applications.

In the present work, the kinetics of the Staphylococcus epidermidis inactivation and specific contributions of $\cdot \mathrm{OH}, \mathrm{O}_{2}^{--}$and $\mathrm{H}_{2} \mathrm{O}_{2}$ to the bactericidal process were studied using two photocatalytic disinfection settings; one with a resin- $\mathrm{TiO}_{2}$ photocatalytic surface and one with suspended photocatalytic $\mathrm{TiO}_{2}$ nanoparticles.

\section{Materials and Methods}

\subsection{Bacterial Strain}

Staphylococcus epidermidis (CCUG 18000 A) was used in the antibacterial tests. A frozen aliquot of S. epidermidis was inoculated into $10 \mathrm{ml}$ Brain Heart Infusion (BHI) broth (Fluka, Sigma-Aldrich Chemie GmbH, Steinheim, Germany) and cultured at $37^{\circ} \mathrm{C}$ with agitation to late log phase. S. epidermidis were collected by centrifugation (4000 rpm, 10 min, EBA 30 centrifuge, Hettich, Tuttlingen, Germany) and then re-suspended in sterile phosphate buffered saline (PBS).

\subsection{Photocatalytic Surfaces}

For tests involving photocatalytic surfaces, a resin- $\mathrm{TiO}_{2}$ nanocomposite was prepared by incorporating $\mathrm{TiO}_{2}$ nanoparticles in a resin matrix. This nanocomposite material has been proved to possess photocatalytic properties capable of effectively killing bacteria on the surface [22]. The resin consists of two monomers, 2,2-bis [4(2-hydroxy-3-methacryloxypropoxy) phenyl-propane (BisGMA, Polysciences Europe GmbH, Eppelheim, Germany) and 2-hydroxyethyl methacrylate (HEMA, Sigma-Aldrich, Schnelldorf, Germany), in a 55/45 wt/wt ratio. The photoinitiator and coinitiators were added as follows: $0.5 \mathrm{~mol} \%$ camphorquinone (CQ); $0.5 \mathrm{~mol} \%$ 2-(dimethylamino) ethyl methacrylate (DMAEMA); 0.5 mol\% ethyl-4-(dimethylamino) benzoate (EDMAB); and 1 wt\% diphenyliodoniumhexafluoro phosphate (DPIHP) (all from Sigma-Aldrich, Steinheim, Germany). The resin- $\mathrm{TiO}_{2}$ nanocomposite was made by mixing $20 \mathrm{wt} \%$ of $\mathrm{TiO}_{2}$ nanoparticles (P25, Evonik Industries AG, Germany) in the resinmonomer mixture. These nanoparticles consist of both the anatase and rutile crystalline phases, which can be observed in previous characterizations of this resin- $\mathrm{TiO}_{2}$ nanocomposite [23]. The mixture was placed in an ultrasonic bath for 1 hour to decrease nanoparticle aggregation. The mixture was then cast in Teflon molds (cylindrical: diameter $8 \mathrm{~mm}$, thickness $1 \mathrm{~mm}$ ) and polymerization was induced under $460 \mathrm{~nm}$ light (Blue LEX GT1200, Monitex, Taiwan) for $30 \mathrm{~s}$ under $\mathrm{N}_{2}$ flow. Pure resin disks without nanoparticles were prepared and used as controls.

\subsection{Antibacterial Tests}

To examine the bactericidal effect of the ROS, three types of scavengers, D-Mannitol, SOD and Catalase (Sigma-Aldrich Chemie GmbH, Steinheim, Germany), were employed to block $\bullet \mathrm{OH}, \mathrm{O}_{2}^{--}$and $\mathrm{H}_{2} \mathrm{O}_{2}$, respectively, in the antibacterial tests. The concentrations of scavengers were adjusted to achieve optimal blocking of respective ROS.

In order to investigate how the antibacterial effect of ROS is affected by the distance between bacteria and $\mathrm{TiO}_{2}$ catalysts, two series of antibacterial tests were performed, one utilizing photocatalytic resin- $\mathrm{TiO}_{2}$ nanocomposite disks as the active antibacterial material and the other utilizing photocatalytic $\mathrm{TiO}_{2}$ nanoparticles (P25) in a bacterial suspension as the active antibacterial material. See Figure 1 for a schematic representation of the two test scenarios.

\subsubsection{Antibacterial Tests with Photocatalytic Surfaces}

The sample suspensions for antibacterial tests with photocatalytic surfaces were made by mixing the S. epidermidis suspension with solutions in PBS containing various combinations of the ROS scavengers D-Mannitol, SOD and Catalase. Table 2 displays a summary of the different suspensions and their constituents used in the antibacterial tests with photocatalytic surfaces.

Resin- $\mathrm{TiO}_{2}$ disks were used for test series I-1 to I-5 while pure resin disks without $\mathrm{TiO}_{2}$ nanoparticles were used for test series I-6 to examine the bactericidal effect of UV light alone. For all antibacterial tests, $10 \mu \mathrm{l}$ of 
(a)

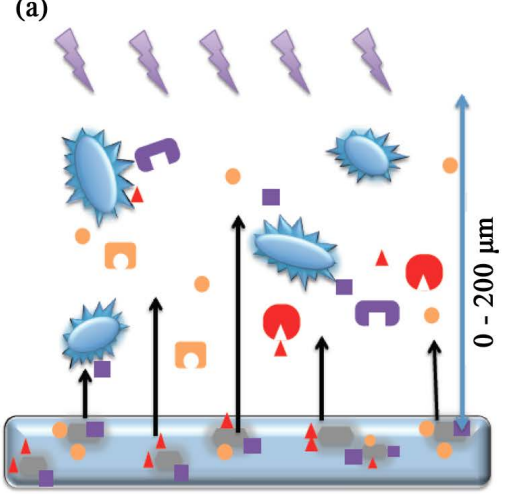

(b)

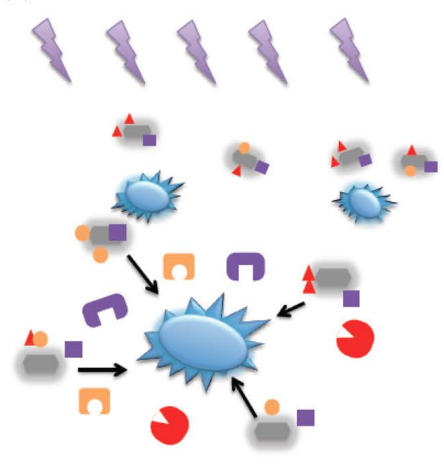

UV $\quad \Delta$ ROS RO ROS scavengers

(a)
$\mathrm{TiO}_{2}$ nanoparticles bacteria

(b)

Figure 1. (a) Antibacterial tests utilizing photocatalytic resin- $\mathrm{TiO}_{2}$ disk as active antibacterial material. Under UV irradiation the $\mathrm{TiO}_{2}$ nanoparticles $\left(\mathrm{P}_{25}\right)$ imbedded in the resin produce ROS, which then diffuse (indicated by arrows) from the composite material into the overlying layer of bacterial suspension having a thickness of up to 200 $\mu \mathrm{m}$; (b) Antibacterial tests utilizing photocatalytic $\mathrm{TiO}_{2}$ nanoparticles $\left(\mathrm{P}_{25}\right)$ dispersed in a bacterial suspension. ROS generated from UV illumination of the nanoparticles diffuse (indicated by arrows) into the suspension and come into contact with the bacteria.

Table 2. Compositions of suspensions for tests with photocatalytic surfaces (“ $\sqrt{ }$ ” indicates constituent was added and " $\times$ " means the contrary).

\begin{tabular}{cccccc}
\hline Test & ROS blocked & S. epidermidis $\mathbf{O D}_{660}=\mathbf{1}$ & Mannitol $\mathbf{1 ~} \mathbf{~ m g} / \mathbf{m l}$ & SOD $\mathbf{~} \mathbf{~ m g} / \mathbf{m l}$ & Catalase $\mathbf{~} \mathbf{~ m g} / \mathbf{m l}$ \\
\hline $\mathrm{I}-1$ & $\cdot \mathrm{OH}$ & $\sqrt{ }$ & $\sqrt{ }$ & $\times$ & $\times$ \\
$\mathrm{I}-2$ & $\mathrm{O}_{2}^{--}$ & $\sqrt{ }$ & $\times$ & $\sqrt{ }$ & $\times$ \\
$\mathrm{I}-3$ & $\mathrm{H}_{2} \mathrm{O}_{2}$ & $\sqrt{ }$ & $\sqrt{ }$ & $\sqrt{ }$ & $\sqrt{ }$ \\
$\mathrm{I}-4$ & All ROS & $\sqrt{ }$ & $\times$ & $\times$ & $\sqrt{ }$ \\
$\mathrm{I}-5$ & None & $\sqrt{ }$ & $\times$ & $\times$ & $\times$ \\
$\mathrm{I}-6$ & Control test for & UV light alone & $\sqrt{ }$ & & \\
\hline
\end{tabular}

sample suspension was spread evenly over the surface of each disk (see test schematic, Figure 1(a)). With a disk diameter of $8 \mathrm{~mm}$, the resulting layer of suspension on the surface is calculated to be approximately $200 \mu \mathrm{m}$ thick. The surfaces of the disks were then irradiated with a UV-A diode $(\lambda=365 \mathrm{~nm}$, NSCU033B (T), Nichia, Japan) with an intensity of $10 \mathrm{~mW} / \mathrm{cm}^{2}$ (UV light meter, UV-340, Lutron), and irradiation times of $0,3,6,10$, 15, 20, 30 and 40 minutes (three disks at each irradiation time and each test series).

After the UV-A irradiation, each disk was immediately transferred into a well in a 48-well plate containing $500 \mu \mathrm{l}$ of PBS. The 48-well plate was then shaken at $500 \mathrm{rpm}$ for 2 minutes (Talboys incubating orbital shaker, Troemner, USA) to re-suspend the bacteria from the disk surfaces. From the $500 \mu \mathrm{l}$ of bacteria suspension, 100 $\mu 1$ was transferred to a metabolic activity test well containing a $900 \mu$ l solution of BHI broth and resazurin (2.5 $\mu \mathrm{g} / \mathrm{ml}$ ). Concurrently, a bacterial dilution series (from 1 to $10^{-8}$ times the untreated bacterial concentration) was prepared to provide a standard curve for quantitative determination of bacterial viability. The plates were cultured at $37^{\circ} \mathrm{C}$ and the transition from resazurin (blue and non-fluorescent) to resorufin (pink and fluorescent) due to bacterial metabolism was monitored by both fluorescent intensity measurements (excitation at $530 \mathrm{~nm}$ and emission at $590 \mathrm{~nm}$; for high viability samples with shorter UV irradiation time) and time needed for color change from blue to pink (visually; for low viability samples with longer UV irradiation time) [24]. Bacterial viability of each sample was determined by correlation to the standard curve, which was derived from the known bacterial concentrations. 


\subsubsection{Antibacterial Tests with Suspended $\mathrm{TiO}_{2}$ Nanoparticles}

The sample suspensions for antibacterial tests with suspended $\mathrm{TiO}_{2}$ nanoparticles were prepared by mixing $\mathrm{TiO}_{2}$ $\mathrm{P}_{25}$ nanoparticles and $S$. epidermidis with solutions in PBS containing various combinations of the ROS scavengers D-Mannitol, SOD and Catalase. Table 3 displays a summary of the different suspensions and their constituents used in the antibacterial tests with suspended $\mathrm{TiO}_{2}$ nanoparticles.

For the antibacterial test series II-1to II-5, $1 \mathrm{ml}$ of sample suspension was added to a well in a 12-well plate. The well was then irradiated with a UV-A diode with an intensity of $10 \mathrm{~mW} / \mathrm{cm}^{2}$. The plate and UV-A lamp were fixed to an orbital shaker operating at $250 \mathrm{rpm}$ during irradiation to ensure uniform mixing of bacteria and nanoparticles. A series of $10 \mu \mathrm{l}$ samples were removed from the well at $0,3,6,10,15,20,30$ and 40 minutes during illumination. Each sample was added to a $900 \mu \mathrm{l}$ solution of BHI broth and resazurin $(2.5 \mu \mathrm{g} / \mathrm{ml})$, and bacterial viability was analyzed using the metabolic activity test as described above in test series I. Each test series was performed in triplicate.

\subsubsection{Optimization of Scavenger Concentrations}

Different concentrations were tested first to ensure adequate ROS blocking by scavengers; the optimal concentration was determined when an increase of concentration did not provide a further increase in blocking effect.

For mannitol, SOD and Catalase, a concentration series of $0.05,0.1,0.3,0.5,1,3,5$ and $10 \mathrm{mg} / \mathrm{ml}$ was tested. The results showed that for all three scavengers, increasing the concentration above $1 \mathrm{mg} / \mathrm{ml}$ did not appreciably increase its capability to block the antibacterial effect of the photocatalytic process.

\section{Results}

\subsection{Antibacterial Tests with Photocatalytic Surfaces}

Figure 2 displays the results of antibacterial tests with photocatalytic surfaces as bacterial viability reduction compared to the untreated bacterial samples (i.e. 0 min UV irradiation) versus UV irradiation time.
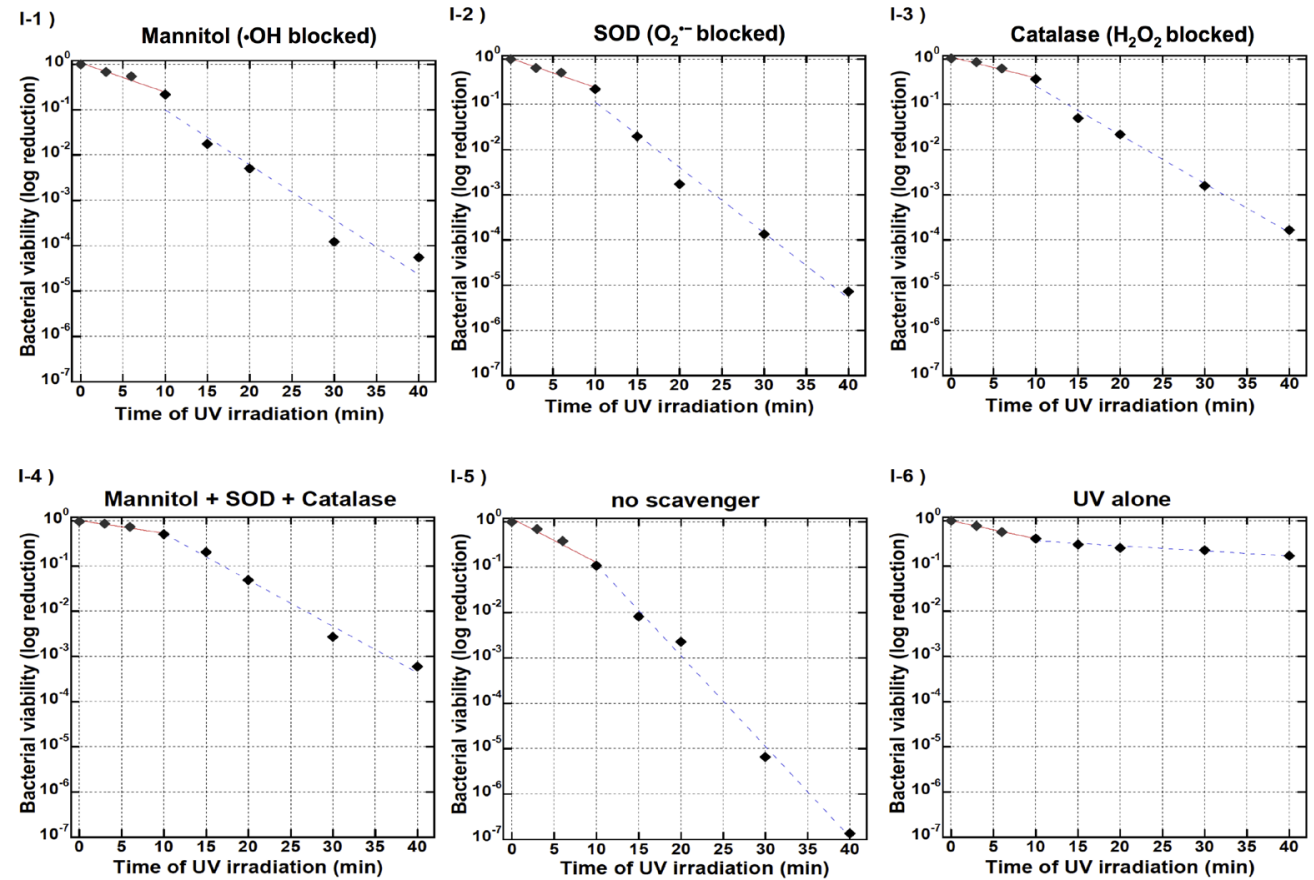

Figure 2. Log reduction of $S$. epidermidis viability as a function of UV irradiation time. In panels I-1 to I-5 the presence of ROS scavengers is indicated with antibacterial tests of the resin- $\mathrm{TiO}_{2}$ disks. Panel I-6 displays the log reduction of $S$. epidermidis viability when non-photocatalytic pure resindisks were used and, thus, shows the effect of UV irradiation alone. Lines are exponential curve fits to the data representing the disinfection rates. Each data point is the mean of three samples and standard deviations are within $11 \%$. 
Table 3. Compositions of suspensions for antibacterial tests with suspended $\mathrm{TiO}_{2}$ nanoparticles (“ $\sqrt{ }$ ” indicates constituent was added and “ $x$ ” means the contrary).

\begin{tabular}{|c|c|c|c|c|c|c|}
\hline Test & ROS blocked & $\begin{array}{c}\mathrm{TiO}_{2} \\
3 \mathrm{mg} / \mathrm{ml}\end{array}$ & $\begin{array}{l}\text { S. epidermidis } \\
\mathbf{O D}_{660}=1\end{array}$ & $\begin{array}{l}\text { Mannitol } \\
1 \mathrm{mg} / \mathrm{ml}\end{array}$ & $\begin{array}{l}\text { SOD } \\
1 \mathrm{mg} / \mathrm{ml}\end{array}$ & $\begin{array}{l}\text { Catalase } \\
1 \mathrm{mg} / \mathrm{ml}\end{array}$ \\
\hline II-1 & $\cdot \mathrm{OH}$ & $\sqrt{ }$ & $\sqrt{ }$ & $\sqrt{ }$ & $x$ & $x$ \\
\hline II-2 & $\mathrm{O}_{2}^{\cdot-}$ & $\sqrt{ }$ & $\sqrt{ }$ & $x$ & $\sqrt{ }$ & $x$ \\
\hline II-3 & $\mathrm{H}_{2} \mathrm{O}_{2}$ & $\sqrt{ }$ & $\sqrt{ }$ & $x$ & $x$ & $\sqrt{ }$ \\
\hline II-4 & All ROS & $\sqrt{ }$ & $\sqrt{ }$ & $\sqrt{ }$ & $\sqrt{ }$ & $\sqrt{ }$ \\
\hline II-5 & None & $\sqrt{ }$ & $\sqrt{ }$ & $x$ & $x$ & $x$ \\
\hline
\end{tabular}

The photocatalytic effect of the resin- $\mathrm{TiO}_{2}$ disks can be seen by comparing panels I-5 and I-6 in Figure 2. After 40 min of UV illumination, the antibacterial effect of the UV light alone resulted in less than 1 log bacterial viability reduction on the non-photocatalytic pure resin surface while an additional 6 log reduction could be achieved from the photocatalytic effect of the resin- $\mathrm{TiO}_{2}$ surface with the same UV dose. From panels I-1, I-2 and I-3 we can infer the relative contributions to the antibacterial effect from $\bullet \mathrm{OH}, \mathrm{O}_{2}^{--}$and $\mathrm{H}_{2} \mathrm{O}_{2}$, respectively, by comparison to panel I-5 in which all ROS are active. When all three of these ROS are simultaneously blocked, see panel I-4, we do not see a decrease in antibacterial effect equivalent to that of UV light alone, shown in panel I-6, indicating that either the scavengers are not $100 \%$ efficient in blocking the ROS, or that other antibacterial agents in addition to the three in focus here are in play when illuminating the resin- $\mathrm{TiO}_{2}$ disks with UV light.

In Figure 2, all tests involving the photocatalytic resin- $\mathrm{TiO}_{2}$ disks exhibited two regions of bacterial viability reduction, an initial step of lower bacterial killing rate within about the first 10 minutes of UV irradiation (Step 1) followed by a step with an increased bacterial killing rate (Step 2). In each step, a disinfection rate was determined according to the Chick-Watson disinfection model [25] that describes the relationship between number of viable bacteria $N$ and the application time ( $t$ ) of bactericidal treatment (in our case UV irradiation time):

$$
N / N_{0}=\exp (-k t)
$$

where $k$ is the disinfection rate constant and $N_{0}$ is the initial number of bacteria at $t=0$. Equation (8) was applied to the data in Figure 2 and the obtained disinfection rate constants are listed in Table 4 along with the log reduction of bacterial viability after 10 and 40 minutes. Additionally, the log reduction of bacterial viability after 10 and 40 minutes for antibacterial tests I- 1 to I-6 are displayed in Figure 3 to aid in the comparison of ROS contributions to the total antibacterial effect.

\subsection{Antibacterial Tests with Suspended $\mathrm{TiO}_{2}$ Nanoparticles}

The results of the antibacterial tests with suspended $\mathrm{TiO}_{2}$ nanoparticles $\left(\mathrm{P}_{25}\right)$ are shown as bacterial viability reduction compared to the untreated bacterial samples (i.e. 0 min UV irradiation) versus UV irradiation time in Figure 4.

From panels II- 1 to II- 4 we can infer the relative contributions to the antibacterial effect from $\cdot \mathrm{OH}, \mathrm{O}_{2}^{--}$and $\mathrm{H}_{2} \mathrm{O}_{2}$, respectively, by comparison to panel II-5 in which all ROS are active (i.e. where no scavengers were used). When all scavengers are used in the antibacterial tests, the antibacterial effect is the lowest, as expected (panel II-4). The log reduction achieved in each test after 40 minutes UV irradiation is shown in Figure 5. A control antibacterial test with only UV irradiation is not available because the opaque $\mathrm{TiO}_{2}$ nanoparticles decreases the UV irradiation through the suspension by an unknown factor; a control test without nanoparticles would thus subject bacteria to a entirely different UV dose than in a suspension with nanoparticles.

A common behavior of all tests with suspended $\mathrm{TiO}_{2}$ nanoparticles is the decrease in rate of inactivation with increasing UV irradiation after approximately 20 minutes. This can likely be attributed to the aggregation of nanoparticles (and perhaps bacteria) and the subsequent partial precipitation observed during the experiments. Equation (8) was therefore applied to the data in the first 20 minutes in determining the disinfection rate constants displayed in Table 5. 


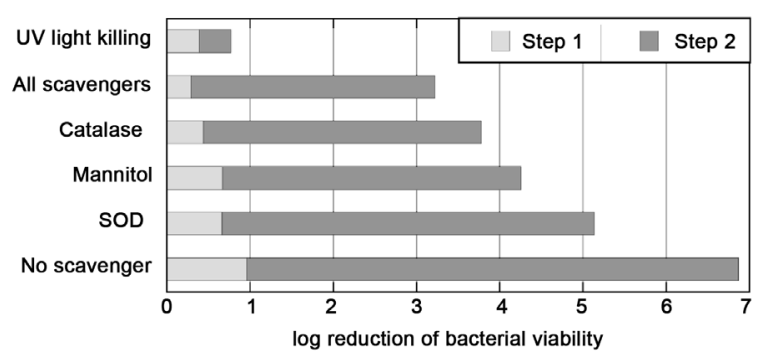

Figure 3. The log reduction of bacterial viability after 10 (Step 1) and 40 (Step 2) minutes UV irradiation in antibacterial tests I-1 to I-6.
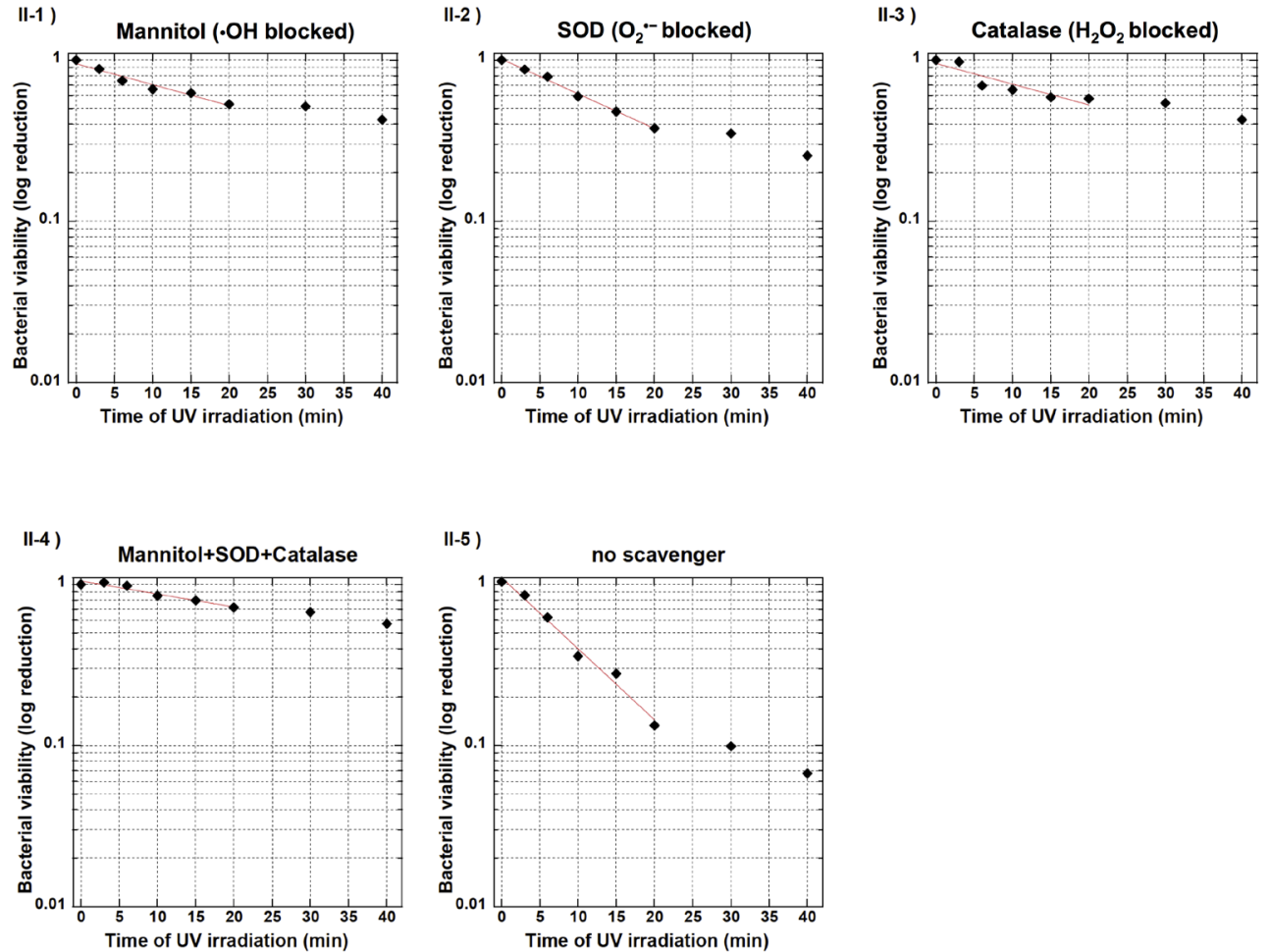

Figure 4. Log reduction of S. epidermidis as a function of UV irradiation time in antibacterial tests with suspended $\mathrm{TiO}_{2}$ nanoparticles. The presence of ROS scavengers is indicated above the individual panels. Lines are exponential curve fits to the data representing the disinfection rates. Each data point is the mean of three measurements and standard deviations are within $5 \%$.

Table 4. Log reduction of bacterial viability and the disinfection rate constants $(k)$ of the antibacterial tests with photocatalytic surfaces. Steps 1 and 2 refer to the time range 0 - $10 \mathrm{~min}$ and $10-40 \mathrm{~min}$, respectively.

\begin{tabular}{|c|c|c|c|c|c|}
\hline \multirow{2}{*}{ Test } & \multirow{2}{*}{ Scavenger added } & \multicolumn{2}{|c|}{ Log reduction achieved } & \multicolumn{2}{|c|}{ Disinfection rate constant $(k)\left[\mathrm{s}^{-1}\right]$} \\
\hline & & After 10 min & After $40 \mathrm{~min}$ & Step 1 & Step 2 \\
\hline Test I-1 & Mannitol ( $\bullet O H$ blocked) & 0.67 & 4.26 & 0.149 & 0.279 \\
\hline Test I-2 & $\operatorname{SOD}\left(\mathrm{O}_{2}^{--}\right.$blocked $)$ & 0.66 & 5.14 & 0.147 & 0.333 \\
\hline Test I-3 & Catalase $\left(\mathrm{H}_{2} \mathrm{O}_{2}\right.$ blocked $)$ & 0.44 & 3.78 & 0.106 & 0.249 \\
\hline Test I-4 & Mannitol, SOD, Catalase & 0.29 & 3.22 & 0.064 & 0.236 \\
\hline Test I-5 & No scavengers & 0.96 & 6.87 & 0.223 & 0.460 \\
\hline Test I-6 & Control test of UV alone & 0.39 & 0.77 & 0.092 & 0.026 \\
\hline
\end{tabular}




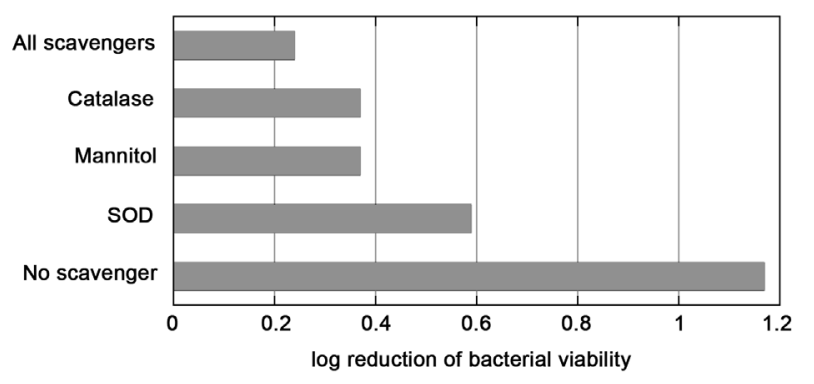

Figure 5. The log reduction of bacterial viability after $40 \mathrm{mi}-$ nutes UV irradiation in the tests with suspended photocatalytic $\mathrm{TiO}_{2}$ nanoparticles.

Table 5. Log reduction of bacterial viability and the disinfection rate constants $(k)$ of the antibacterial tests with suspended photocatalytic $\mathrm{TiO}_{2}$ nanoparticles.

\begin{tabular}{cccc}
\hline Test & Scavenger added & $\begin{array}{c}\text { Log reduction achieved } \\
\text { after } \mathbf{4 0 ~} \mathbf{~ m i n}\end{array}$ & $\begin{array}{c}\text { Disinfection rate constant }(\boldsymbol{k}) \\
{\left[\mathbf{s}^{-1} \mathbf{~ f o r ~ f i r s t ~ 2 0 ~} \mathbf{~ m i n}\right.}\end{array}$ \\
\hline Test II-1 & Mannitol $(\cdot \mathrm{OH}$ blocked $)$ & 0.37 & 0.0299 \\
Test II-2 & SOD $\left(\mathrm{O}_{2}^{--} \quad\right.$ blocked $)$ & 0.59 & 0.0496 \\
Test II-3 & Catalase $\left(\mathrm{H}_{2} \mathrm{O}_{2}\right.$ blocked $)$ & 0.37 & 0.0296 \\
Test II-4 & Mannitol, SOD, Catalase & 0.24 & 0.0186 \\
Test II-5 & No scavengers & 1.17 & 0.1016 \\
\hline
\end{tabular}

\section{Discussion}

The results of the antibacterial tests in test series I with the resin- $\mathrm{TiO}_{2}$ surface and test series II with the suspended $\mathrm{TiO}_{2}$ nanoparticles differ in both the way the different ROS contribute to the overall bacterial inactivation as well as the disinfection kinetics. In tests with the resin- $\mathrm{TiO}_{2}$ surface we can see from Figure 2 and Figure 3 that $\mathrm{H}_{2} \mathrm{O}_{2}$ provides the largest contribution to the inactivation of S. epidermidis because the addition of its scavenger, catalase, resulted in the greatest decrease in log reduction compared to tests in which all ROS were active. In comparison, $\cdot \mathrm{OH}$ and $\mathrm{H}_{2} \mathrm{O}_{2}$ were seen to be the most important contributors to the bacterial inactivation in tests with the suspended $\mathrm{TiO}_{2}$ nanoparticles (see Figure 4 and Figure 5).

The finding that $\mathrm{H}_{2} \mathrm{O}_{2}$ is the prominent ROS in tests with the resin- $\mathrm{TiO}_{2}$ surface is in agreement with previous research in which $\mathrm{H}_{2} \mathrm{O}_{2}$ was also found to be the most effective ROS in the inactivation of Escherichia coli when the bacteria were separated from the $\mathrm{TiO}_{2}$ by a $50 \mu \mathrm{m}$ porous membrane [21]. It could be expected that $\mathrm{H}_{2} \mathrm{O}_{2}$ would be more effective at longer ranges due to the longer lifetime of this ROS in comparison to the $\cdot \mathrm{OH}$ and $\mathrm{O}_{2}^{--}$radicals. In test series I with the resin- $\mathrm{TiO}_{2}$ surface, there are two reasons that the ROS would have to act at a distance to achieve an antibacterial effect: 1 ) bacteria could potentially lie at a distance of up to $200 \mu \mathrm{m}$ from the photocatalytic surface, and 2) the ROS generated at the surface of imbedded $\mathrm{TiO}_{2}$ nanoparticles may have to diffuse to the surface of the resin- $\mathrm{TiO}_{2}$ nanocomposite disk, a scenario which is not unlike the one with the porous membrane in the previously mentioned study [21].

In test series II involving the suspended nanoparticles, both $\bullet \mathrm{OH}$ and $\mathrm{H}_{2} \mathrm{O}_{2}$ appear to play the most important roles in the bacterial inactivation. The $\cdot \mathrm{OH}$ radical has previously been found to be the primary ROS in the inactivation of E. coli in a suspension of UV illuminated $\mathrm{P} 25 \mathrm{TiO}_{2}$ nanoparticles [18]. We can expect the short-lifetime $\cdot \mathrm{OH}$ to be effective in this test scenario due to the abundance of nanoparticles in the suspension and the use of the orbital shaker, ensuring a very short diffusion distance to the bacteria. At the same time, in our test setup the abundance of nanoparticles resulted in an opaque solution that also likely prevented UV from reaching nanoparticles further in the suspension. The suspension was stirred during the tests, but it is still likely that longer diffusion distances were required to reach some bacteria, thus explaining the importance of $\mathrm{H}_{2} \mathrm{O}_{2}$ in the inactivation process. Further support for the hypothesis of the screening effect in the tests with the $\mathrm{TiO}_{2}$ nanoparticle suspension is the fact that the disinfection rates in test series II are much lower than those recorded in test series 
I. Both test series used the same bacterial concentrations and light intensities, so normally one would have expected a greater bactericidal effect with suspended nanoparticles in which the photocatalytic surfaces were on average much closer to the bacteria. In all cases, it is not straightforward to interpret the results obtained by using scavengers for the different ROS since it must be kept in mind that there are multiple pathways for the creation of, for example, $\mathrm{H}_{2} \mathrm{O}_{2}$ (c.f. Equations (6) and (7)) and thus blocking one ROS may also affect the abundance of another ROS in the system.

Returning to Figure 2 and Figure 4, we can observe the disinfection kinetics of the two antibacterial test series where the Chick-Watson disinfection model is also applied to the data. This first order kinetic model is simplistic, but it has found application in several investigations of bacterial inactivation from $\mathrm{TiO}_{2}$ induced photocatalysis [8]. However, in tests with the resin- $\mathrm{TiO}_{2}$ surface we find a more complex behavior with two distinct disinfection rates. This two-stage phenomenon has been previously observed [8] and is somewhat similar to the delayed Chick-Watson model [8]. Whereas the delayed Chick-Watson model incorporates an initial lag phase in the disinfection process, the initial step observed in this study exhibits a reduced disinfection rate compared to the second step. A possible explanation for this could be presence of the resin matrix surrounding the $\mathrm{TiO}_{2}$ nanoparticles, which may result in a delay in the ROS achieving maximum concentration due to the time required for diffusion of the ROS to the surface. Indeed, the same two-step kinetics is not seen in test series II in which the $\mathrm{TiO}_{2}$ nanoparticles are not encased in the resin material. On the other hand, in the tests of UV light alone using resin disks, the disinfection rate decreases after approximately 10 min instead of increasing, which may suggest that, on the contrary, the bacteria partially recover from the UV exposure. Finally, it has been noted in the literature that different bacterial strains can show different disinfection kinetics with $\mathrm{TiO}_{2}$ induced photocatalysis [8]. In this study, the Gram-positive S. epidermidis was investigated. This bacterium is catalase-positive, which provides it with a certain resistance against $\mathrm{H}_{2} \mathrm{O}_{2}$. Thus, it would be of interest in future studies to investigate the disinfection kinetics and role of the ROS with other Gram-positive and Gram-negative bacterial strains.

\section{Conclusion}

The kinetics of photocatalytic $\mathrm{TiO}_{2}$ inactivation of Staphylococcus epidermidis and specific contributions of $\cdot \mathrm{OH}, \mathrm{O}_{2}^{--}$and $\mathrm{H}_{2} \mathrm{O}_{2}$ to the bactericidal process were studied using two photocatalytic disinfection scenarios. In antibacterial tests against $S$. epidermidis with a layer of bacterial suspension on photocatalytic resin- $\mathrm{TiO}_{2}$ disks, $\mathrm{H}_{2} \mathrm{O}_{2}$ was found to be the most efficient ROS component contributing to the antibacterial effect. Disinfection kinetics showed a two-step behavior with an initial region having a lower disinfection rate followed by a higher rate region after $10 \mathrm{~min}$ of UV irradiation. By contrast, in antibacterial tests with suspended bacteria and photocatalytic $\mathrm{TiO}_{2}$ nanoparticles, $\bullet \mathrm{OH}$ and $\mathrm{H}_{2} \mathrm{O}_{2}$ showed equal significance in the bacterial inactivation. As well, a typical Chick-Watson disinfection kinetics behavior with a steady disinfection rate was observed instead of the two-step kinetics in the resin- $\mathrm{TiO}_{2}$ tests.

\section{Acknowledgements}

We greatly acknowledge The Carl Trygger Foundation, The Göran Gustafsson Foundation, The Swedish Research Council, Vinnova and The Swedish Foundation for Strategic Research for financially supporting this work.

\section{References}

[1] Matsunaga, T., Tomoda, R., Nakajima, T. and Wake, H. (1985) Photoelectrochemical Sterilization of Microbial-Cells by Semiconductor Powders. FEMS Microbiology Letters, 29, 211-214. http://dx.doi.org/10.1111/j.1574-6968.1985.tb00864.x

[2] Liou, J.W. and Chang, H.H. (2012) Bactericidal Effects and Mechanisms of Visible Light-Responsive Titanium Dioxide Photocatalysts on Pathogenic Bacteria. Archivum Immunologiae Et Therapiae Experimentalis, 60, 267-275. http://dx.doi.org/10.1007/s00005-012-0178-X

[3] Lilja, M., Welch, K., Åstrand, M., Engqvist, H. and Strømme, M. (2012) Effect of Deposition Parameters on the Photocatalytic Activity and Bioactivity of $\mathrm{TiO}_{2}$ Thin Films Deposited by Vacuum Arc on Ti-6Al-4V Substrates. Journal of Biomedical Materials Research Part B-Applied Biomaterials, 100B, 1078-1085. http://dx.doi.org/10.1002/jbm.b.32674

[4] Foster, H.A., Ditta, I.B., Varghese, S. and Steele, A. (2011) Photocatalytic Disinfection Using Titanium Dioxide: Spectrum and Mechanism of Antimicrobial Activity. Applied Microbiology and Biotechnology, 90, 1847-1868. 
http://dx.doi.org/10.1007/s00253-011-3213-7

[5] Lilja, M., Forsgren, J., Welch, K., Åstrand, M., Engqvist, H. and Strømme, M. (2012) Photocatalytic and Antimicrobial Properties of Surgical Implant Coatings of Titanium Dioxide Deposited though Cathodic Arc Evaporation. Biotechnology Letters, 34, 2299-2305. http://dx.doi.org/10.1007/s10529-012-1040-2

[6] Dalrymple, O.K., Stefanakos, E., Trotz, M.A. and Goswami, D.Y. (2010) A Review of the Mechanisms and Modeling of Photocatalytic Disinfection. Applied Catalysis B-Environmental, 98, 27-38. http://dx.doi.org/10.1016/j.apcatb.2010.05.001

[7] Wu, X.Z., Lingyue, M. and Akiyama, K. (2005) Chemiluminescence Study of Active Oxygen Species Produced by $\mathrm{TiO}_{2}$ Photocatalytic Reaction. Luminescence, 20, 36-40. http://dx.doi.org/10.1002/bio.800

[8] Cermenati, L., Pichat, P., Guillard, C. and Albini, A. (1997) Probing the $\mathrm{TiO}_{2}$ Photocatalytic Mechanisms in Water Purification by Use of Quinoline, Photo-fenton Generated OH Radicals and Superoxide Dismutase. Journal of Physical Chemistry B, 101, 2650-2658. http://dx.doi.org/10.1021/jp962700p

[9] Okuda, M., Tsuruta, T. and Katayama, K. (2009) Lifetime and Diffusion Coefficient of Active Oxygen Species Generated in $\mathrm{TiO}_{2}$ Sol Solutions. Physical Chemistry Chemical Physics, 11, 2287-2292. http://dx.doi.org/10.1039/b817695g

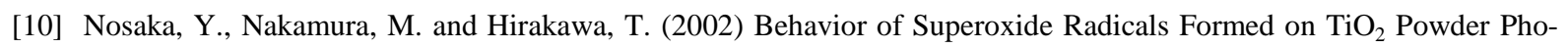
tocatalysts Studied by a Chemiluminescent Probe Method.Physical Chemistry Chemical Physics, 4, 1088-1092. http://dx.doi.org/10.1039/b108441k

[11] Popham, P.L. and Novacky, A. (1991) Use of Dimethyl-Sulfoxide to Detect Hydroxyl Radical during Bacteria-Induced Hypersensitive Reaction. Plant Physiology, 96, 1157-1160. http://dx.doi.org/10.1104/pp.96.4.1157

[12] Pezzuto, J.M. and Park, E.J. (2007) Autoxidation and Antioxidants. In: Swarbrick, J., Ed., Encyclopedia of Phamaceutical Technology, 3rd Edition, Informa Healthcare, New York, 139-154.

[13] Nakano, M., Sugioka, K., Ushijima, Y. and Goto, T. (1986) Chemiluminescence Probe with Cypridina Luciferin Analog, 2-Methyl-6-Phenyl-3,7-Dihydroimidazo[1,2-a]Pyrazin-3-One, for Estimating the Ability of Human-Granulocytes to Generate $\mathrm{O}_{2}^{-}$. Analytical Biochemistry, 159, 363-369. http://dx.doi.org/10.1016/0003-2697(86)90354-4

[14] Sunada, K., Watanabe, T. and Hashimoto, K. (2003) Studies on Photokilling of Bacteria on $\mathrm{TiO}_{2}$ Thin Film. Journal of Photochemistry and Photobiology A-Chemistry, 156, 227-233. http://dx.doi.org/10.1016/S1010-6030(02)00434-3

[15] Hirakawa, K., Mori, M., Yoshida, M., Oikawa, S. and Kawanishi, S. (2004) Photo-Irradiated Titanium Dioxide Catalyzes Site Specific DNA Damage via Generation of Hydrogen Peroxide. Free Radical Research, 38, 439-447. http://dx.doi.org/10.1080/1071576042000206487

[16] Maness, P.C., Smolinski, S., Blake, D.M., Huang, Z., Wolfrum, E.J. and Jacoby, W.A. (1999) Bactericidal Activity of Photocatalytic $\mathrm{TiO}_{2}$ Reaction: Toward an Understanding of Its Killing Mechanism. Applied and Environmental Microbiology, 65, 4094-4098.

[17] Kiwi, J. and Nadtochenko, V. (2004) New Evidence for $\mathrm{TiO}_{2}$ Photocatalysis during Bilayer Lipid Peroxidation. Journal of Physical Chemistry B, 108, 17675-17684. http://dx.doi.org/10.1021/jp048281a

[18] Cho, M., Chung, H., Choi, W. and Yoon, J. (2004) Linear Correlation between Inactivation of E. coli and OH Radical Concentration in $\mathrm{TiO}_{2}$ Photocatalytic Disinfection. Water Research, 38, 1069-1077. http://dx.doi.org/10.1016/j.watres.2003.10.029

[19] Wu, P.G., Imlay, J.A. and Shang, J.K. (2010) Mechanism of Escherichia coli Inactivation on Palladium-Modified Nitrogen-Doped Titanium Dioxide.Biomaterials, 31, 7526-7533. http://dx.doi.org/10.1016/j.biomaterials.2010.06.032

[20] Cho, M. and Yoon, J. (2008) Measurement of OH Radical CT for Inactivating Cryptosporidium Parvum Using Photo/ Ferrioxalate and Photo/TiO ${ }_{2}$ Systems. Journal of Applied Microbiology, 104, 759-766. http://dx.doi.org/10.1111/j.1365-2672.2007.03682.x

[21] Kikuchi, Y., Sunada, K., Iyoda, T., Hashimoto, K. and Fujishima, A. (1997) Photocatalytic Bactericidal Effect of TiO 2 Thin Films: Dynamic View of the Active Oxygen Species Responsible for the Effect. Journal of Photochemistry and Photobiology A-Chemistry, 106, 51-56.

[22] Welch, K., Cai, Y.L., Engqvist, H. and Strømme, M. (2010) Dental Adhesives with Bioactive and On-Demand Bactericidal Properties .Dental Materials, 26, 491-499. http://dx.doi.org/10.1016/j.dental.2010.01.008

[23] Cai, Y., Strømme, M. and Welch, K. (2013) Photocatalytic Antibacterial Effects Are Maintained on Resin-Based TiO 2 Nanocomposites after Cessation of UV Irradiation. PLoS One, 8, Article ID: e75929. http://dx.doi.org/10.1371/journal.pone.0075929

[24] Welch, K., Cai, Y. and Strømme, M. (2012) A Method for Quantitative Determination of Biofilm Viability. Journal of Functional Biomaterials, 3, 418-431. http://dx.doi.org/10.3390/jfb3020418

[25] Watson, H.E. (1908) A Note on the Variation of the Rate of Disinfection with Change in the Concentration of the Disinfectant. Journal of Hygiene, 8, 536-542. http://dx.doi.org/10.1017/S0022172400015928 
Scientific Research Publishing (SCIRP) is one of the largest Open Access journal publishers. It is currently publishing more than 200 open access, online, peer-reviewed journals covering a wide range of academic disciplines. SCIRP serves the worldwide academic communities and contributes to the progress and application of science with its publication.

Other selected journals from SCIRP are listed as below. Submit your manuscript to us via either submit@scirp.org or Online Submission Portal.
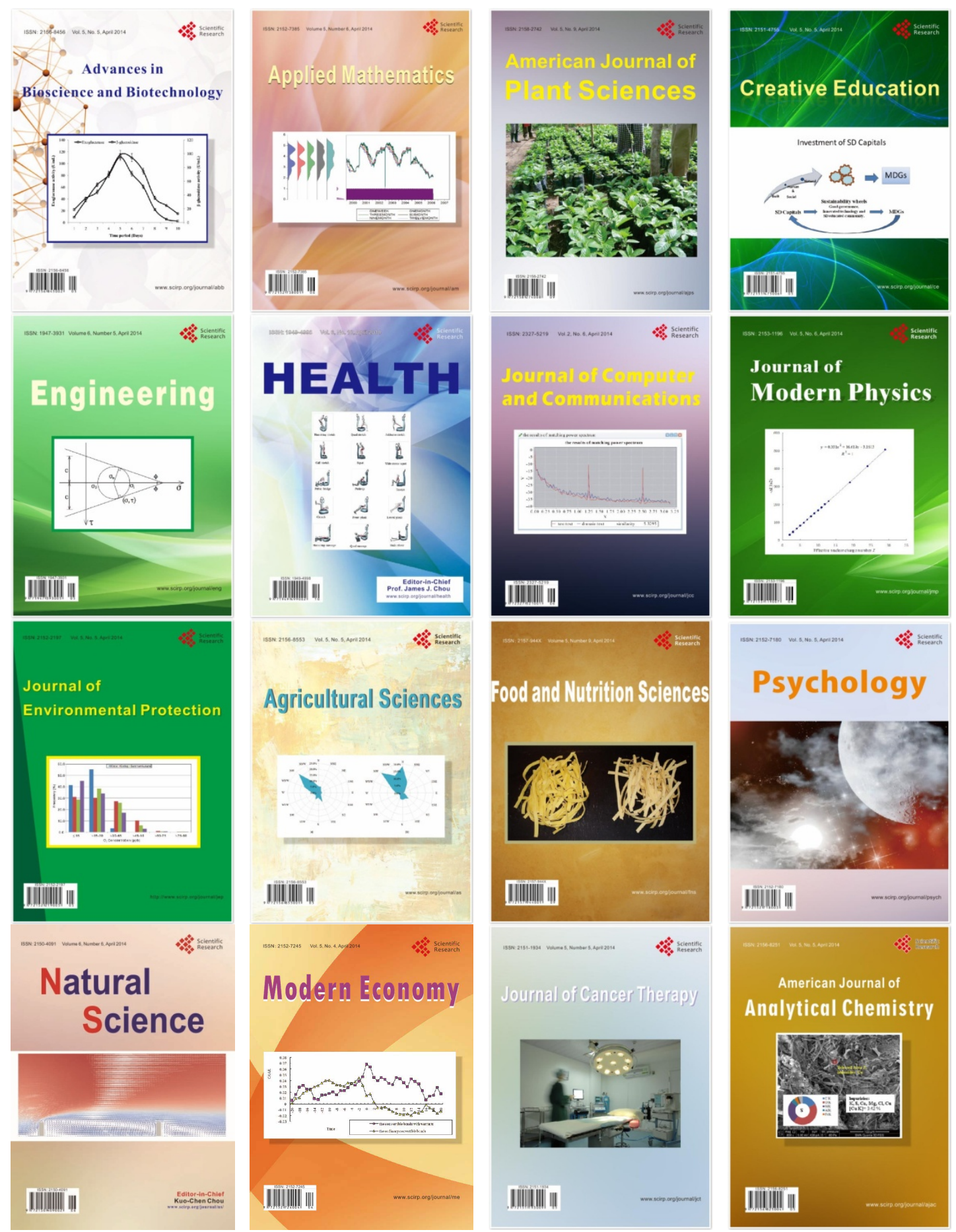